\title{
NOTE
}

\section{Mangrove use by the invasive lionfish Pterois volitans}

\author{
Andrew B. Barbour ${ }^{1, *}$, Meredith L. Montgomery ${ }^{1}$, Alecia A. Adamson ${ }^{1}$, \\ Edgardo Díaz-Ferguson ${ }^{2}$, Brian R. Silliman ${ }^{2}$
}

\author{
${ }^{1}$ School of Forest Resources and Conservation, Program of Fisheries and Aquatic Sciences, 7922 NW 71 st Street, \\ University of Florida, Gainesville, Florida 32653, USA \\ ${ }^{2}$ Department of Biology, PO Box 110600 University of Florida, Gainesville, Florida 32611, USA
}

\begin{abstract}
Lionfish Pterois volitans are successful invasive predators in the sub-tropical and tropical Western Atlantic. Their invasion of coral reef ecosystems is a major conservation concern, as previous studies in the Western Atlantic have found that this top predator (1) occurs at higher densities and forages more successfully than in its native range, (2) lacks significant predators as an adult, and (3) reduces reef fish recruitment. The effects of lionfish on coral reef communities have been examined, but it is not known if these predators use critical non-reef habitat such as mangroves, which serve as nurseries for many reef fish species. To investigate lionfish usage of non-reef critical habitat, we compared population size-structure and stomach contents of $P$. volitans in mangroves and coral reefs on the island of San Salvador, Bahamas. In each habitat, $>80 \%$ of lionfish stomachs contained prey items with similar gut content wet weight $(0.98 \pm 0.35 \mathrm{~g}$ in reef habitat and $0.99 \pm 0.43 \mathrm{~g}$ in mangrove habitat) despite differences in total lionfish length $(231.1 \pm 10.30 \mathrm{~mm}$ in reef habitat and 176.3 $\pm 16.83 \mathrm{~mm}$ in mangrove habitat). Prey items detected by genetic analysis included individuals of the families Palaemonidae, Penaeidae, Gobidae, Scaridae, Mullidae and Grammatidae. These results demonstrate that lionfish colonize and feed in mangrove habitat in the Bahamas. Further study of lionfish outside reef habitat is required to understand the effects of this marine invasion.
\end{abstract}

KEY WORDS: Marine invasion · Nursery habitat $\cdot$ Recruitment $\cdot$ San Salvador $\cdot$ Stomach contents Scorpaenidae $\cdot$ Genetic analysis

\section{INTRODUCTION}

Two species of invasive Indopacific lionfish, Pterois volitans and P. miles, invaded Western Atlantic waters in the 1990s and have established populations ranging from North Carolina to the Caribbean (Whitfield et al. 2002, Hamner et al. 2007). P. volitans is now common in the Bahamas and appears to have rapidly expanding populations (Albins \& Hixon 2008). Bahamian populations of $P$. volitans are estimated to be denser than in their native range (Green \& Côté 2009), while P. miles has not been found in Bahamian waters (Freshwater et al. 2009). The lionfish invasion could have serious effects on native ecology due to a lack of known predators as an adult (Maljkovic et al. 2008), higher prey consumption rates in the Atlantic than in their native range (Fishelson 1997), an ability to consume a wide range of trophic levels and reduce reef fish recruitment (Albins \& Hixon 2008), and extensive dispersal capabilities (Fishelson 1975).

Most Bahamian lionfish research has focused on coral reef habitat; no information exists on colonization effects in mangrove habitat-a critical habitat that influences reef community structure and overall reef fish biomass (Nagelkerken et al. 2002, Mumby et al. 2004, Adams et al. 2006). Lionfish utilizing these habitats may affect recruitment to reef habitat by reducing the survival of reef fish in juvenile habitat through predation and/or competition, exacerbating known lionfish effects on reef fish recruitment. 
The aim of this study was to examine lionfish presence in Bahamian mangroves, comparing mangrove and reef lionfish through size-structure and stomach content analyses.

\section{MATERIALS AND METHODS}

Study site. Collection of Pterois volitans occurred within Graham's Harbor $\left(24^{\circ} 07^{\prime} \mathrm{N} 74^{\circ} 27^{\prime} \mathrm{W}\right)$ and Pigeon Creek $\left(28^{\circ} 58^{\prime} \mathrm{N} 74^{\circ} 29^{\prime} \mathrm{W}\right)$, San Salvador, Bahamas. Graham's Harbor is a protected, low energy area on the northeast end of San Salvador characterized by multiple fringing, patch, and barrier reefs, as well as artificial structure and seagrass beds. Sampling within the harbor occurred at multiple sites: Dump Reef $\left(24^{\circ} 07^{\prime} 47^{\prime \prime} \mathrm{N}, 74^{\circ} 27^{\prime} 35^{\prime \prime} \mathrm{W}\right)$, Government Pier $\left(24^{\circ} 07^{\prime} 12^{\prime \prime} \mathrm{N}, 74^{\circ} 28^{\prime} 14^{\prime \prime} \mathrm{W}\right)$, Golans Reef (240 $07^{\prime} 47^{\prime \prime} \mathrm{N}$, $\left.74^{\circ} 27^{\prime} 35^{\prime \prime} \mathrm{W}\right)$, and an unnamed hardened structure site $\left(24^{\circ} 07^{\prime} 11^{\prime \prime} \mathrm{N}, 74^{\circ} 27^{\prime} 57^{\prime \prime} \mathrm{W}\right)$. Pigeon Creek is a tidal mangrove creek in the southeast corner of San Salvador, characterized by dense mangroves (Rhizophora mangle, Avicennia germinans), seagrass beds, a pock-marked $\mathrm{CaCO}_{3}$ substrate, and a central channel $\sim 1$ to $3 \mathrm{~m}$ deep. Pigeon Creek is a presumed nursery habitat for reef fish (Diehl et al. 1988).

Sampling procedure. We collected Pterois volitans using hand nets while snorkeling (Fishelson 1997). Sampling occurred before noon in Pigeon Creek, and throughout the day in Graham's Harbor. We measured total wet weight and total length, and removed prey items and remnants from the stomach and esophagus. We weighed contents wet and identified by microscope to the lowest possible taxonomic level.

Genetic analysis. DNA extraction of Pterois volitans and gut contents was conducted using the CTAB (cetyl trimethylammonium bromide) isolation protocol. PCR amplification of 2 mitochondrial genes 16S rRNA and cytochrome c oxidase subunit I (COI) was performed using the universal primers $A R$ and BR for 16S rRNA, and HCOI and LCOI for COI, with the following PCR conditions: $1 \mathrm{mM}$ deoxynucleoside triphosphates (dNTPs), $3 \mathrm{mM} \mathrm{MgCl}_{2}$ and $10 \mu \mathrm{M}$ primers. PCR products were cleaned using the QIAGEN QIAquick PCR purification kit and sequenced using an ABI-PRISM electronic sequencer. Sequence products were edited using Geneius 4.6. and blasted using the GenBank database. For both $P$. volitans and gut contents, only 16S rRNA was positively amplified and considered for taxonomic identification.

Genetic data analysis. Summary statistics including nucleotide diversity $(\pi)$, and the standard neutrality test, Tajima's $D$, were calculated using DNAsP v.5.0 both overall and by location. Population differen- tiation among locations was estimated using the $S_{\mathrm{nn}}$ 'nearest neighbor' statistic of Hudson (2000), using DNAsp v.5.0 and by $F_{\text {ST }}$ pairwise tests implemented in ARLEQUIN 3.11.

Statistical analysis. We calculated catch per unit effort (CPUE) as a measure of number of fish caught, per habitat type, divided by hours spent searching the habitat. To test if data conformed to assumptions of homogeneity of variances and normality, we used visual analysis of standardized residuals versus fitted values, F-tests, and Shapiro-Wilks tests. We compared mean total length, mean total weight, and mean stomach content weight using Welch's 2-sample $t$-tests. Statistical significance for all analyses was determined at $\alpha=0.05$ and results are reported $\pm 1 \mathrm{SE}$.

\section{RESULTS}

Mean CPUE (fish caught $\mathrm{h}^{-1}$ ) was 2.6 times higher in Pigeon Creek (mangrove habitat) $(0.67 \pm 0.33$ vs. $0.26 \pm 0.088)$. We found mean total length to be greater in Graham's Harbor (reef habitat) $(231.1 \pm 10.30$ vs. $176.3 \pm 16.83 \mathrm{~mm})(t=2.78, \mathrm{p}=0.0126)$.

Diet analysis was performed on 22 specimens of Pterois volitans: 10 from Graham's Harbor and 12 from Pigeon Creek. We found contents in $80 \%$ of Graham's Harbor and $83 \%$ of Pigeon Creek lionfish stomachs. Mean wet weight of diet contents from Graham's Harbor was $0.98 \pm 0.35 \mathrm{~g}$ compared to $0.99 \pm 0.43 \mathrm{~g}$ from Pigeon Creek. Of the 22 stomachs examined, 13 contained identifiable food items, including whole fish, fish parts and whole shrimp. Six families and three genera were positively identified as prey items using 16S rRNA mitochondrial DNA: Palaemonidae and Scaridae (Scarus)* in Graham's Harbor, and Penaeidae (3 ind.), Gobidae, Mullidae (Pseudopeneus), and Grammatidae (Gramma)* in Pigeon Creek. Samples confirmed with $99 \%$ similarity at the genus level denoted by $\left({ }^{*}\right)$.

A $445 \mathrm{bp}$ section of the 16S rRNA mitochondrial gene of lionfish tissue was analyzed in 23 samples: 11 from Graham's Harbor and 12 from Pigeon Creek. Genetic analysis revealed that all lionfish 16S rRNA sequences belong to the species Pterois volitans. Nucleotide diversity registered a value of $\pi=0.022$ at Graham's Harbor and $\pi=0.024$ at Pigeon Creek, while Tajima's neutrality test showed values of $D_{\mathrm{T}}=$ -0.61 and -1.48 for Graham's Harbor and Pigeon Creek, respectively. The genetic differentiation parameters $S_{\text {nn }}$ (Hudson 2000) and $F_{\text {ST }}$ pairwise revealed a weak structure among the studied locations for $P$. volitans and suggest the existence of a single population on the island of San Salvador, Bahamas $\left(S_{\mathrm{nn}}=0.41\right.$, not significant; $\left.F_{\mathrm{ST}}=-0.051\right)$. 


\section{DISCUSSION}

This study presents the first evidence that lionfish use mangrove habitat. Our CPUE results qualitatively suggest (Pine et al. 2003) a higher lionfish density in Pigeon Creek (mangrove habitat) than in Graham's Harbor (reef habitat). Despite a smaller average Pterois volitans size in Pigeon Creek, fish from both habitats had similar gut content weight. Prey item diversity (number of families) was also higher in Pigeon Creek. Moreover, genetic analysis supports previous observations that $P$. volitans is the only species of lionfish present in the Bahamas (Freshwater et al. 2009). Genetic data suggest the existence of a single population of $P$. volitans on San Salvador, which is consistent with the strong connectivity and reduced structure observed in previous studies (Freshwater et al. 2009).

Lionfish colonization of Pigeon Creek occurred rapidly, as our group has studied Pigeon Creek for the past $6 \mathrm{yr}$, but had not seen lionfish in this creek until the present study (B. R. Silliman pers. obs.). We caution extrapolation of these results due to pseudoreplication of habitat types and the small sample size collected from study sites. Also, our exploration of Pigeon Creek was spatially restricted to the lower reach, approximately $1.0 \mathrm{~km}$ from the mouth, an area that may be used by non-resident species to utilize food resources (Layman \& Silliman 2002). Although we explored only one mangrove system in the Bahamas, conversations with scientists in the Bahamas suggest lionfish colonization of mangrove habitat is occurring and imminent (P. Mumby, J. Bruno, L. Akins pers. comm.).

Additionally, we frequently observed juvenile Nassau grouper Epinephelus striatus residing near similarly sized lionfish in Pigeon Creek, suggesting direct competition for resting sites and potential competition for food resources near resting sites. Predation upon and competition with juvenile fish is likely to decrease recruitment to the adult population through an increase in juvenile mortality (Houde 1987, Connell \& Jones 1991). As lionfish have been shown to drastically reduce reef fish recruitment (Albins \& Hixon 2008), it is highly likely that their presence in mangrove habitat poses an immediate threat to economically and ecologically important fish families (e.g. Scaridae, Serranidae) utilizing mangrove systems as nursery habitat (Mumby et al. 2004, 2007, Koenig et al. 2007).

Molecular methods confirmed that lionfish consume over a broad trophic range, including (1) invertivores, (2) herbivores, (3) invertebrates, and (4) planktivores. This is of concern as invasions are especially destructive when the invasive species lacks predators and is polyphagous (Pimm 1987). Another concern is the potential for lionfish prey consumption to generate powerful trophic cascades (Silliman \& Bertness 2002). For example, lionfish could decrease herbivorous reef fish populations vital for controlling macroalgal growth. Without these controls, macroalgal proliferation can inhibit coral reef recruitment, growth, and recovery after physical disturbance (Mumby et al. 2006, Mumby et al. 2007). Albins \& Hixon (2008) demonstrated that lionfish presence on experimental patch reefs reduced overall reef fish recruitment by $79 \%$, including herbivorous parrotfishes. This novel consumption of native herbivorous reef species by an invasive may enhance macroalgal production on coral reefs, contributing to widespread phase shifts on Caribbean coral reefs (Hughes 1994, McCook 1999, Bellwood et al. 2004).

It may be prudent to expand current management actions to include the targeting of lionfish in mangrove habitat. Attention to lionfish is primarily devoted to areas of high human traffic (e.g. coral reefs); therefore, less trafficked areas should be explored for their presence, especially since there is potential for rapid colonization. Additional work needs to be conducted to determine if lionfish presence in mangroves decreases survival of native juveniles, subsequently affecting adult communities. Since lionfish occurred in Pigeon Creek (mangrove habitat) at a smaller average size, and mangrove habitat acts as a nursery for various reef fishes, we think it prudent to suggest an ontological investigation of lionfish habitat usage.

Acknowledgements. We are indebted to The Gerace Research Centre and its staff on San Salvador Island, Bahamas and the University of Florida Tropical Marine Biology Class for logistical support for this research. J. Griffin, M. Lauretta, D. Behringer, A. Adams, and P. O'Rouke provided reviews, and D. Gwinn and $\mathrm{M}$. Allen reviewed the statistical analyses. We also thank G. Moyer and the Fish Technology Center of the US Fish and Wild Life Service, Warm Spring, Georgia for the support in using the electronic sequencer and PCR equipment during the genetic analysis.

\section{LITERATURE CITED}

Adams AJ, Dahlgren CP, Kellison GT, Kendall MS and others (2006) Nursery function of tropical back-reef systems. Mar Ecol Prog Ser 318:287-301

Albins MA, Hixon MA (2008) Invasive Indo-Pacific lionfish Pterois volitans reduce recruitment of Atlantic coral-reef fishes. Mar Ecol Prog Ser 367:233-238

Bellwood DR, Hughes TP, Folke C, Nyström M (2004) Confronting the coral reef crisis. Nature 429:827-833

Connell SD, Jones GP (1991) The influence of habitat complexity on postrecruitment processes in a temperate reef fish population. J Exp Mar Biol Ecol 151:271-294

Diehl F, Mellon D, Garrett R, Elliott N (1988) Field guide to the invertebrates of San Salvador Island, Bahamas. Bahamian Field Station Research Paper, San Salvador

Fishelson L (1975) Ethology and reproduction of pteroid fishes found in the Gulf of Aqaba (Red Sea) especially Dendro- 
chirus brachypterus (Cuvier) (Pteroidae, Teleostei). Pubbl Stn Zool Napoli 39:635-656

Fishelson L (1997) Experiments and observations on food consumption, growth and starvation in Dendrochirus brachypterus and Pterois volitans (Pteroinae, Scorpaenidae). Environ Biol Fishes 50:391-403

Freshwater DW, Hines A, Parham S, Wilbur A and others (2009) Mitochondial control region sequence analyses indicate dispersal from the US East Coast as the source of the invasive Indo-Pacific lionfish Pterois volitans in the Bahamas. Mar Biol 156:1213-1221

Green SJ, Côté IM (2009) Record densities of Indo-Pacific lionfish on Bahamian coral reefs. Coral Reefs 28:107

> Hamner RM, Freshwater DW, Whitfield PE (2007) Mitchondrial cytochrome $b$ analysis reveals two invasive lionfish species with strong founder effects in the western Atlantic. J Fish Biol 71:214-222

Houde ED (1987) Fish early life dynamics and recruitment variability. Am Fish Soc Symp 2:17-29

Hudson RR (2000) A new statistic to detect genetic differentiation. Genetics 155:2011-2014

Hughes TP (1994) Catastrophes, phase shifts, and large-scale degradation of a Caribbean coral reef. Science 265: $1547-1551$

Koenig CC, Coleman FC, Eklund AM, Schull J, Uleand J (2007) Mangroves as essential nursery habitat for goliath grouper (Epinephelus itajara). Bull Mar Sci 80:567-586

Layman CA, Silliman BR (2002) Preliminary survey and diet analysis of juvenile fishes of an estuarine creek on Andros Island, Bahamas. Bull Mar Sci 70:199-210

Maljkovic A, Van Leeuwen TE, Cove SN (2008) Predation on the invasive red lionfish, Pterois volitans (Pisces: Scor-

Editorial responsibility: Ivan Nagelkerken,

Nijmegen, Netherlands paenidae), by native groupers in the Bahamas. Coral Reefs 27:501

McCook LJ (1999) Macroalgae, nutrients and phase shifts on coral reefs: scientific issues and management consequences for the Great Barrier Reef. Coral Reefs 18: $357-367$

Mumby PJ, Edwards AJ, Arias-Gonzales JE, Lindeman KC, and others (2004) Mangroves enhance the biomass of coral reef fish communities in the Caribbean. Nature 427: 533-536

- Mumby PJ, Dahlgren CP, Harborne AR, Kappel CV and others (2006) Fishing, trophic cascades, and the process of grazing on coral reefs. Science 311:98-101

- Mumby PJ, Hastings A, Edwards HJ (2007) Thresholds and the resilience of Caribbean coral reefs. Nature 450:98-101

> Nagelkerken I, Roberts CM, van der Valde G, Dorenbosch M, van Riel MC, Cocheret de al Morinière E, Nienhuis PH (2002) How important are mangroves and seagrass beds for coral-reef fish? The nursery hypothesis tested on an island scale. Mar Ecol Prog Ser 244:299-305

$>$ Pimm SL (1987) Determining the effects of introduced species. Trends Ecol Evol 2:106-108

Pine WE, Pollock KH, Hightower JE, Kwak TJ, Rice JA (2003) A review of tagging methods for estimating fish population size and components of mortality. Fish Res 28:10-23

Silliman BR, Bertness MD (2002) A trophic cascade regulates salt marsh primary production. Proc Natl Acad Sci USA 99:10500-10505

> Whitfield PE, Gardner T, Vives SP, Gilligan MR, Courtenay WR, Ray GC, Hare JA (2002) Biological invasion of the Indo-Pacific lionfish Pterois volitans along the Atlantic coast of North America. Mar Ecol Prog Ser 235:289-297

Submitted: August 6, 2009; Accepted: October 14, 2009

Proofs received from author(s): February 3, 2010 